\title{
Labial salivary gland biopsy in Sjögren's disease
}

\author{
D. M. CHISHOLM AND D. K. MASON \\ From the Department of Oral Medicine, University of Glasgow Dental Hospital and School, Glasgow
}

\begin{abstract}
SYNOPSIS A labial biopsy technique is described and was used to study 40 patients with connective tissue disease and 60 postmortem subjects. More than one focus of lymphocytes per $4 \mathrm{sq} \mathrm{mm}$ of minor salivary tissue was found to be a consistent finding in patients with Sjögren's disease. The labial biopsy is shown to be a further valuable investigative procedure in such patients.
\end{abstract}

Sjögren's disease, first described in 1933 (Sjögren, 1933), consists of chronic inflammation of the lacrimal and salivary glands leading to dryness of the eye (keratoconjunctivitis sicca) and dryness of the mouth (xerostomia), and in a proportion of cases, lacrimal and/or salivary gland enlargement may also be present. In 50 to $60 \%$ of patients the disease may be associated with a connective tissue disorder, usually rheumatoid arthritis but occasionally also with polymyositis, polyarteritis nodosa, progressive systemic sclerosis (scleroderma) and systemic lupus erythematosus. The term 'sicca complex' is applied to those cases of Sjögren's disease not associated with rheumatoid arthritis or other connective tissue disease. In Sjögren's disease a preponderance of female patients, especially in the older age group, is consistently noted.

The histopathological characters of the major salivary glands in Sjögren's disease include parenchymal and ductal alterations. There is a decrease or disappearance of acini, lymphocytic infiltration and hyperplasia of the lining cells of the intraglandular ducts. The formation of epimyoepithelial cell islands has also been described (Morgan and Castleman, 1953) and appears to be a late feature of the disease process.

Though it would be of considerable value to obtain a major salivary gland biopsy in patients with Sjögren's disease, in the majority of cases this cannot be justified because of the inconvenience to patients and the possible complication of salivary fistula. In addition, because of their small size and their relationship to important neurovascular anatomical structures, needle biopsy is unsatisfactory.

Recently, however, in studies on children with fibrocystic disease, Warwick, Bernard, and Meskin (1964) have reported involvement of the labial mucous salivary glands. Furthermore, Calman and Reifman (1966) have reported the involvement of Received for publication 26 February 1968. the minor buccal glands in one patient with Sjögren's syndrome, and Cifarelli, Bennett, and Zaino (1966), Cahn (1967), and Bertram (1967) have described a patient with this condition in which the minor palatal salivary glands showed the characteristic Sjögren's histopathology.

The aims of the present study were:

1 To investigate the histopathological appearances of the minor salivary glands in Sjögren's disease, rheumatoid arthritis, and various other connective tissue diseases.

2 To determine the postmortem appearances of the minor salivary glands, suitable exclusions having been made (Waterhouse and Doniach, 1966).

3 To assess the value of the minor salivary gland biopsy to other methods of investigating salivary gland involvement in Sjögren's disease. These include sialography, measurement of salivary flow rate, and salivary duct antibody findings.

\section{MATERIALS AND METHODS}

PATIENTS Forty patients were studied. The clinical diagnosis, sex distribution, and mean age are shown in Table II.

The diagnosis of Sjögren's disease was based on the criteria described by Bloch, Buchanan, Wohl, and Bunim (1965) and patients were required to have at least two of the three major components of the syndrome. The diagnosis of rheumatoid arthritis was based on the criteria of the American Rheumatism Association (Ropes, Bennett, Cobb, Jacox, and Jessar, 1958). The ophthalmological examination was performed by the method described by Williamson, Cant, Mason, Greig, and Boyle (1967).

ORAL EXAMINATION Each patient was carefully questioned regarding a history of xerostomia and of associated oral and pharyngeal symptoms of Sjögren's disease. In the 10 patients with Sjögren's disease, salivary flow studies were performed using a modified CarlsonCrittenden cup with an outer chamber diameter of $20 \mathrm{~mm}$ and an inner chamber diameter of $10 \mathrm{~mm}$. 
Parotid saliva was collected from each patient under resting conditions and after stimulation with fruit gums and lemon juice. In addition, sialography was performed on these patients using the hydrostatic technique described by Park and Mason (1966).

SALIVARY DUCT ANTIBODY The method described by MacSween, Goudie, Anderson, Armstrong, Murray, Mason, Jasani, Boyle, Buchanan, and Williamson (1967) was used to detect the presence or absence of salivary duct antibody in the sera of all 40 patients studied.

MINOR SALIVARY GLAND BIOPSY The minor salivary glands of the lower lip were chosen for biopsy since they are easily accessible, they lie above the muscle layer, separated from the mucous membrane by a thin layer of fibrous connective tissue and the chance of excessive bleeding is minimal, for the arterial supply to the lip is deep to the gland (Meskin, Bernard, and Warwick, 1964).

With the patient seated in the dental chair and after oral preparation with cetavlon, sterile draping and local anaesthetic infiltration (Xylocaine $2 \%$ ) an ellipse of oral mucous membrane down to the muscle layer was removed (Fig. 1). The biopsy wound was closed using 04 gauge black silk sutures. These were removed after four or five days and in all cases the healing was satisfactory. None of the patients reported undue discomfort, either during or after the biopsy procedure. The biopsy material was fixed in $10 \%$ formaldehyde and standard paraffin preparations were made. The tissue was serially sectioned at $6 \mu$ setting and every ninth or tenth section taken for standard staining with haematoxylin and eosin.

In the same way, minor salivary gland tissue from the lower lip was obtained from 60 postmortem subjects.

Before a case or gland was included in the postmortem series, criteria designed to exclude infection and neoplasm as effective causes of pathological change were applied. Gland lobules were accepted if they were free from duct dilatation, indicating obstruction to flow of secretion, and were free from extravascular polymorphs. Cases were admitted to the series if free of neoplasm of

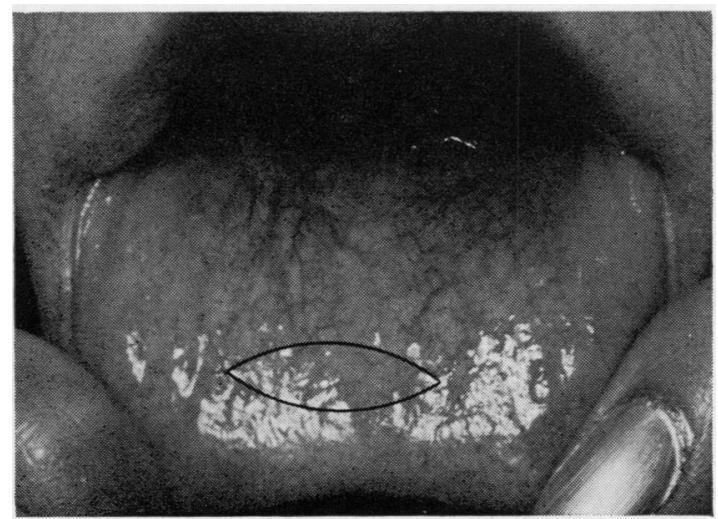

FIG. 1. Area outlined inside lower lip $(3 \mathrm{~cm} \times 0.75 \mathrm{~cm}$ approximately) to show site of labial biopsy. lymphocyte-like cells and had not received cytotoxic drugs within the last three months. Leukaemia patients were excluded (Waterhouse and Doniach, 1966).

GRADING STANDARD FOR LABIAL BIOPSY In order to standardize the area examined and record the degree of histopathological change, the grading standard shown in Table I was employed. All minor salivary gland tissue in the sections was examined and scanned for the presence of lymphocytic foci and/or diffuse lymphocytic infiltration. The approximate area of salivary tissue was measured using a graticule. On some occasions more than, and on others, less than $4 \mathrm{sq} \mathrm{mm}$ were noted, but the results were calculated and expressed as foci per 4 sq $\mathrm{mm}$ of salivary tissue. A 'focus' has been defined as an aggregate of $\mathbf{5 0}$ or more lymphocytes and histiocytes, usually with a few plasma cells placed peripherally (Waterhouse and Doniach, 1966), and these were the criteria adopted by us.

TABLE I

GRADING STANDARD FOR LABIAL SALIVARY GLAND BIOPSY

Grade Lymphocytes per $4 \mathrm{sq} \mathrm{mm}$ of Salivary Tissue

\begin{tabular}{cl}
\hline 0 & Absent \\
1 & Slight infiltrate \\
2 & Moderate infiltrate or less than one focus ${ }^{1}$ \\
3 & One focus \\
4 & More than one focus \\
${ }^{1}$ Focus = an aggregate of 50 or more lymphocytes and histiocytes.
\end{tabular}

The histological appearance of a normal minor salivary gland is shown in Figures $2 a$ and $b$. Lymphocytic involvement of the minor salivary glands in Sjögren's disease is shown in Figures 3 and 4.

\section{HISTOPATHOLOGY}

The results obtained are detailed in Tables II, III and IV.

CLINICAL CASES Of 10 patients with Sjögren's disease, six had more than one focus of lymphocytes per $4 \mathrm{sq} \mathrm{mm}$ (grade 4) and three had one focus per $4 \mathrm{sq} \mathrm{mm}$ (grade 3). One male patient (A5) in this group had a moderate lymphocytic infiltrate without a definite focus (grade 2) being present.

In the group with rheumatoid arthritis four of 10 patients had one focus per $4 \mathrm{sq} \mathrm{mm}$ (grade 3 ). One patient had a slight lymphocytic infiltrate (grade 1) whilst in the remaining five patients lymphocytes were absent in the sections examined (grade 0).

In 20 control patients with various other connective tissue diseases (Table II), two showed slight lymphocytic infiltrations (grade 1). One female patient with scleroderma had one focus per $4 \mathrm{sq} \mathrm{mm}$ (grade 3). This patient gave a history of recurrent aphthous ulceration, but no sicca component of 


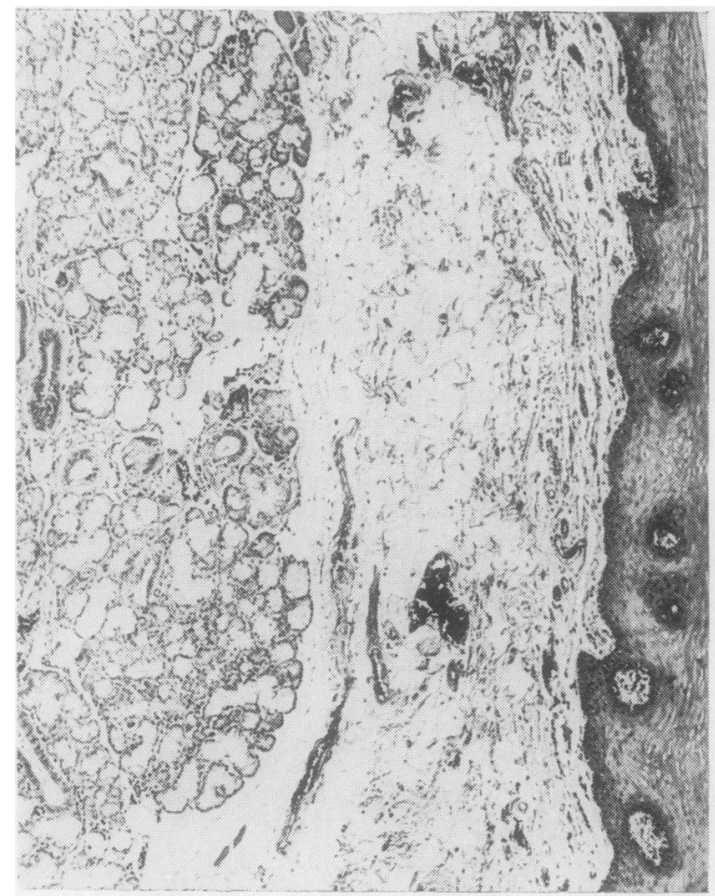

FIG. 2a. Photomicrograph showing proximity of labial mucous glands to mucosal surface. Stained $H . \& E$. $\times 54$.

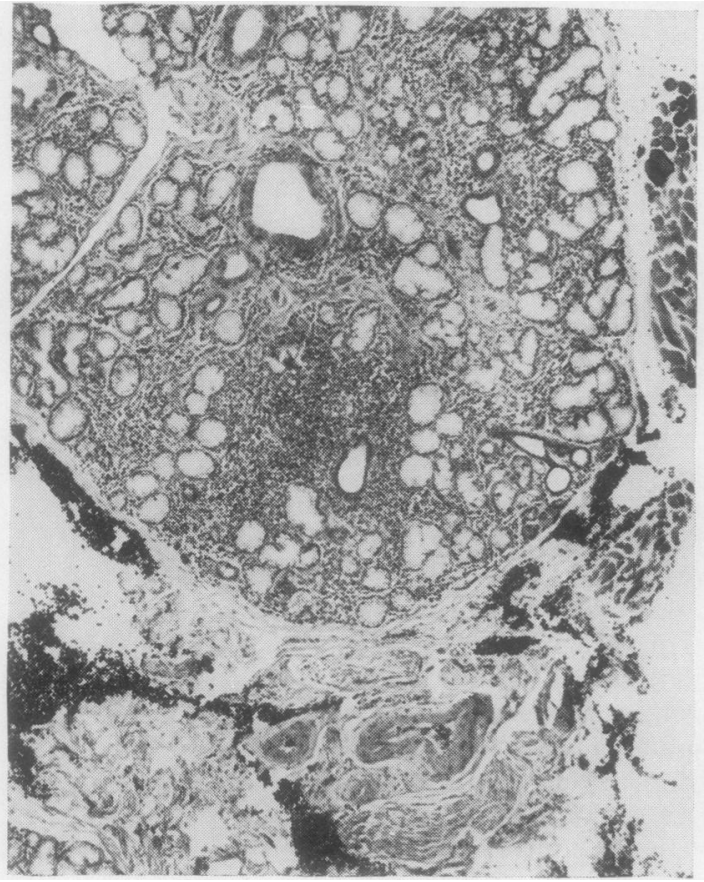

FIG. 3.

FIG. 3. Focal involvement of labial mucous glands: a periductal focus of lymphocytes. Note also the associated diffuse lymphocytic infiltrate. $\times 54$.

FIG. 4. Focal lymphocytic involvement of minor salivary gland in Sjögren's disease. $\quad \times 144$.

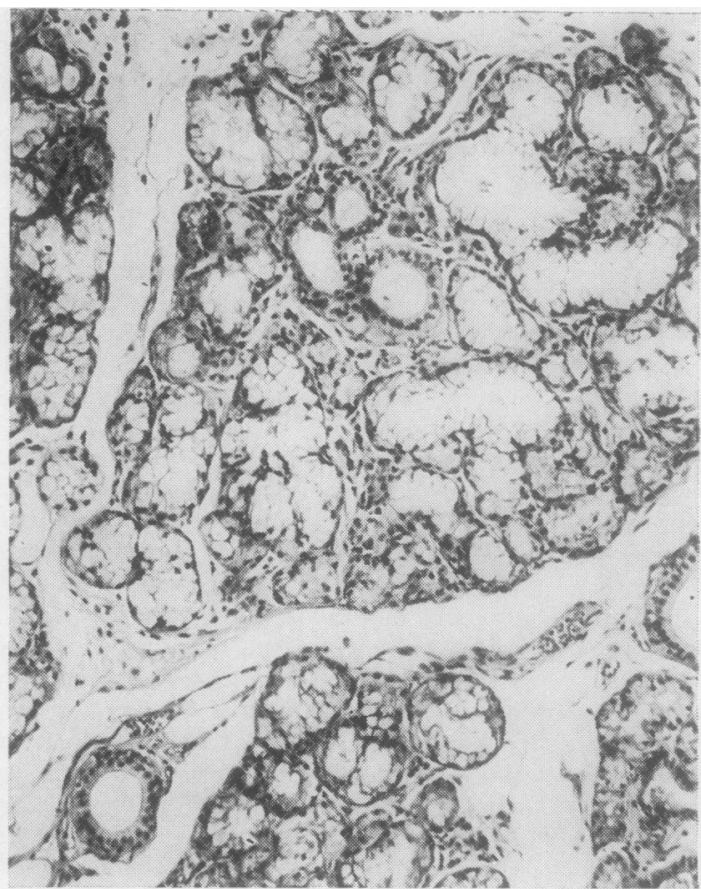

FIG. 2b. Photomicrograph showing normal appearances of labial mucous glands. $\times 144$.

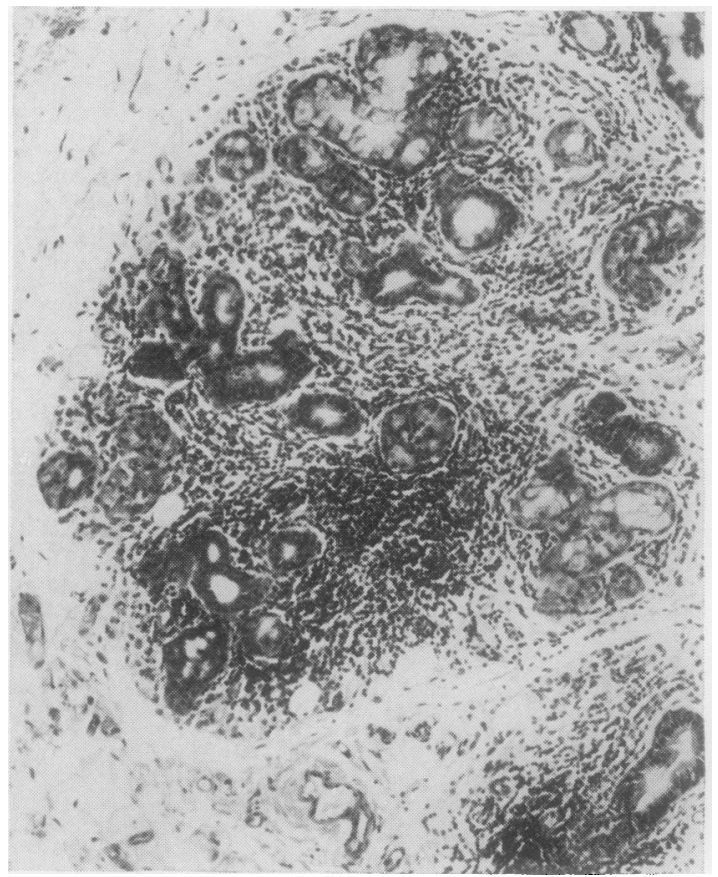

FIG. 4 . 
TABLE II

RESULTS FOR 40 PATIENTS STUDIED

\begin{tabular}{|c|c|c|c|c|c|c|c|c|c|c|}
\hline \multirow[t]{2}{*}{ Clinical Diagnosis } & \multirow[t]{2}{*}{ No. of Patients } & \multirow{2}{*}{$\begin{array}{l}\text { Mean Age } \\
\text { (years) }\end{array}$} & \multicolumn{2}{|l|}{$\operatorname{Sex}$} & \multicolumn{4}{|c|}{ Histopathology Grading } & \multirow[b]{2}{*}{4} & \multirow{2}{*}{$\begin{array}{l}\text { No. with Salivary } \\
\text { Duct Antibody } \\
\text { Positive }\end{array}$} \\
\hline & & & Male & Female & 0 & 1 & 2 & 3 & & \\
\hline Sjögren's disease & 10 & 65 & 2 & 8 & $\mathbf{0}$ & 0 & 1 & 3 & 6 & 6 \\
\hline Rheumatoid arthritis & 10 & 60 & 3 & 7 & 5 & 1 & 0 & 4 & $\mathbf{0}$ & 3 \\
\hline Osteoarthritis & 6 & 58 & 2 & 4 & 6 & 0 & $\mathbf{0}$ & 0 & $\mathbf{0}$ & o \\
\hline Reiter's disease & 6 & 32 & 6 & 0 & 5 & 1 & 0 & $\mathbf{0}$ & $\mathbf{0}$ & $\mathbf{0}$ \\
\hline Psoriatic arthritis & 4 & 42 & 1 & 3 & 3 & 1 & 0 & $\mathbf{0}$ & 0 & $\mathbf{0}$ \\
\hline Scleroderma & 4 & 38 & 1 & 3 & 2 & 0 & $\mathbf{0}$ & 1 & 0 & 0 \\
\hline
\end{tabular}

${ }^{1}$ As described in Table I.

TABLE III

RESULTS OF LABIAL BIOPSY FOR 60 POSTMORTEM SUBJECTS

\begin{tabular}{|c|c|c|c|c|c|c|c|c|}
\hline \multirow[t]{2}{*}{ Age (years) } & \multirow{2}{*}{$\begin{array}{l}\text { Total No. } \\
\text { of Cases }\end{array}$} & \multirow[t]{2}{*}{$\operatorname{Sex}$} & \multirow{2}{*}{$\begin{array}{l}\text { No. of } \\
\text { Cases }\end{array}$} & \multicolumn{5}{|c|}{ Number with Grade of Severity } \\
\hline & & & & 0 & 1 & 2 & 3 & 4 \\
\hline $20-29$ & 3 & $\underset{\mathbf{F}}{\mathbf{M}}$ & $\begin{array}{l}3 \\
0\end{array}$ & 2 & 1 & $\overline{-}$ & $\overline{-}$ & 二 \\
\hline 30-39 & 4 & $\mathbf{M}$ & 3 & - & 2 & 1 & $\bar{z}$ & $=$ \\
\hline $40-49$ & 5 & $\underset{\mathbf{M}}{\mathbf{M}}$ & 2 & $\begin{array}{l}1 \\
2\end{array}$ & 1 & $\overline{1}$ & $=$ & $\bar{z}$ \\
\hline $50-59$ & 11 & $\mathbf{M}$ & $\begin{array}{l}8 \\
3\end{array}$ & $\begin{array}{l}5 \\
1\end{array}$ & 2 & $\begin{array}{l}1 \\
2\end{array}$ & $\bar{z}$ & $\bar{z}$ \\
\hline $60-69$ & 17 & $\mathbf{M}$ & 9 & 4 & $\begin{array}{l}4 \\
2\end{array}$ & 1 & $\bar{z}$ & $\bar{z}$ \\
\hline $70-79$ & 17 & $\mathbf{M}$ & $\begin{array}{l}6 \\
9\end{array}$ & 2 & 3 & 1 & - & 二 \\
\hline 80 & 5 & $\begin{array}{l}\mathbf{F} \\
\mathbf{M}\end{array}$ & $\begin{array}{l}9 \\
1\end{array}$ & 1 & 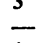 & - & - & 二 \\
\hline & & $\mathbf{F}$ & 4 & 1 & 1 & 2 & - & - \\
\hline
\end{tabular}

TABLE IV

RESULTS FOR 10 PATIENTS WITH SJÖGREN'S DISEASE

$\begin{array}{llllll}\text { Patient } & \text { Age } & \text { Sex } & \begin{array}{l}\text { Histopathology } \\ \text { Grade }\end{array} & \text { Sialography }{ }^{1} & \begin{array}{l}\text { Salivary } \\ \text { Flow } \\ \text { (Parotid) }\end{array}\end{array}$

\begin{tabular}{|c|c|c|c|c|c|c|}
\hline A1 & 54 & $\mathbf{M}$ & 3 & + & + & Weak + ve \\
\hline A2 & 56 & $\mathbf{F}$ & 4 & + & + & 一ve \\
\hline A3 & 59 & $\mathbf{F}$ & 3 & - & - & Strong + ve \\
\hline A4 & 54 & $\mathbf{F}$ & 4 & + & - & Strong + ve \\
\hline A5 & 62 & $\mathbf{M}$ & 2 & + & + & 一ve \\
\hline A6 & 66 & $\mathbf{F}$ & 4 & + & + & Weak + ve \\
\hline A7 & 63 & $\mathbf{F}$ & 3 & + & - & -ve \\
\hline A8 & 56 & $\mathbf{F}$ & 4 & + & + & -ve \\
\hline A9 & 66 & $\mathbf{F}$ & 4 & + & + & Weak + ve \\
\hline A10 & 50 & $\mathbf{F}$ & 4 & - & - & Weak + ve \\
\hline
\end{tabular}

Sjögren's disease was present. The remaining 17 found to be present in the sera of six of 10 patients patients in this group had normal biopsies (grade 0).

POST-MORTEM SUBJECTS The results obtained are shown in Table III. In the 60 postmortem subjects examined, no foci of lymphocytes were seen, but in 16 of them, a moderate lymphocytic infiltrate was noted (grade 2).

\section{SALIVARY DUCT ANTIBODY FINDINGS}

Salivary duct antibody results for the 40 clinical cases are detailed in Table II. The antibody was with Sjögren's disease, and in three of 10 patients with rheumatoid arthritis. The antibody was absent from the sera of all 20 control patients with various other connective tissue diseases.

\section{SIALOGRAPHIC AND SALIVARY FLOW FINDINGS}

In order to assess further the value of the labial biopsy in the diagnosis of Sjögren's disease, the findings of sialographic examination and measurement of salivary flow were noted in these patients. The results obtained are detailed in Table IV. An 
abnormal sialogram was found in eight of 10 patients with Sjögren's disease. In this group six of 10 patients had a decreased parotid salivary flow. Patient A3 had a normal parotid salivary flow and a normal sialogram reading but the labial biopsy showed one focus per $4 \mathrm{sq} \mathrm{mm}$ (grade 3 ).

\section{DISCUSSION}

Although only a moderate series of patients has been investigated, the results show a definite association between foci of lymphocytes involving labial minor salivary glands in both Sjögren's disease and rheumatoid arthritis. Evidence that the association is with both is provided by the positive results in two patients (A5 and A8) (Table IV) who had 'sicca complex' alone. In these patients, the rheumatoid arthritis component of Sjögren's triad was absent.

The degree of involvement was considerably more severe in the Sjögren's group. The typical appearances of Sjögren's syndrome with ductal aberrations and the formation of epimyoepithelial cell islands were not found in any of the sections examined. This lack of ductal change was a feature of the histopathological findings. Whether this was due to the lack of severity of the cases examined, the smallness of the sample, or reflected a later involvement of these minor glands in the disease process is not known. It might also be a feature of the condition when mucous glands alone are involved.

It was interesting to find that four of 10 patients with rheumatoid arthritis alone had one focus per $4 \mathrm{sq} \mathrm{mm}$ (grade 3 ). These results are in keeping with the focal adenitis of the major salivary glands noted in postmortem subjects with rheumatoid arthritis by Waterhouse and Doniach (1966). They suggest that this finding indicates a subclinical form of Sjögren's disease in the rheumatoid patient and further suggest that the lesion may not be progressive since Sjögren's disease appears to be a fairly rare clinical condition compared to rheumatoid arthritis alone.

The results, therefore, indicate the need to follow up those patients with a positive labial biopsy for any manifestations of the 'sicca complex' component of Sjögren's disease.

In 17 of 20 control patients with various other connective tissue diseases, the minor salivary glands were unremarkable histologically. In none of the 60 postmortem subjects was focal adenitis of the minor salivary glands observed. These results indicate that foci of lymphocytes do not normally occur in the minor oral salivary glands. However, it was of interest that of 16 subjects with a grade 2 biopsy, 12 were female. Waterhouse and Doniach (1966) demonstrated a moderate adenitis in the major salivary glands at necropsy in $23 \%$ of females and only $9 \%$ of males. Furthermore, they suggested that the submandibular salivary gland is the most sensitive indicator of salivary gland histopathology in Sjögren's disease. It would be most useful, therefore, to compare the submandibular and labial salivary glands in a series of postmortem cases.

All six patients with Sjögren's disease who had the salivary duct antibody present also had a positive biopsy (grades 3 or 4). In the rheumatoid arthritis group, one of three patients with the salivary duct antibody present had a positive biopsy (grade 3). It will be necessary, however, to study a larger group of patients before a correlation between these findings can be stated.

The results of the labial biopsy would suggest that the technique is a useful investigative procedure in patients with Sjögren's disease. The biopsy is as sensitive a diagnostic test of salivary gland involvement in Sjögren's disease as sialography and measurement of parotid salivary flow rate in the patients studied with this condition.

\section{REFERENCES}

Bloch, K. J., Buchanan, W. W., Wohl, M. J., and Bunim, J. J. (1965). Medicine (Baltimore), 44, 187.

Bertram, U. (1967). Acta odent. scand., 25, suppl. 49.

Cahn, L. (1967). Brit. dent. J. 122, 387.

Calman, H. I., and Reifman, S. (1966). Oral Surg, 21, 158.

Cifarelli, P. S., Bennett, M. J., and Zaino, E. C. (1966). Arch. intern. Med., 117, 429.

MacSween, R. N. M., Goudie, R. B., Anderson, J. R., Armstrong, E., Murray, M. A., Mason, D. K., Jasani, M. K., Boyle, J. A., Buchanan, W. W., and Williamson, J. (1967). Ann. rheum. Dis., 26, 402.

Meskin, L. H., Bernard, B., and Warwick, W. J. (1964). J. Amer. med. Ass., 188, 82

Morgan, W. S., and Castleman, B. (1953). Amer. J. Path., 29, 471.

Park, W. M., and Mason, D. K. (1966). Radiology, 86, 116.

Ropes, M. W., Bennett, G. A., Cobb, S., Jacox, R., and Jessar, R. A. (1958). Bull. rheum. Dis., 9, 175.

Sjögren, H. (1933). Acta opthal. (Kbh.), 11, 1.

Warwick, W. J., Bernard, B., and Meskin, L. H. (1964). Pediatrics, 34,621 .

Waterhouse, J. P., and Doniach, I. (1966). J. Path. Bact., 91, 53.

Williamson, J., Cant, J. S., Mason, D. K., Greig, W. R., and Boyle, J. A. (1967). Brit. J. Ophthal., 51, 721. 